\title{
Evidence for present-day leucogranite pluton growth in Tibet
}

Fabrice Gaillard : Bayerisches Geoinstitut, Universität Bayreuth, D-95440 Bayreuth, Germany

Bruno Scaillet and Michel Pichavant: Institut des Sciences de la Terre d'Orléans, UMR 6113 CNRS-UO, la rue de la Férollerie, 45071, Orléans cedex 2, France

Keywords: leucogranite, Himalayas, Tibet, conductivity, crustal melting.

\begin{abstract}
Several geophysical surveys carried out in southern Tibet have revealed the occurrences of bright spots of high electrical conductivity at 15-20 km depth, corresponding to zones of seismic attenuation and correlated to high heat flow at the surface. Such zones have been variably interpreted as intruding magmas, partially melted middle crust, or concentrations of free fluids. Here we show that experimentally derived electrical conductivities of hydrous granite melts under pressure-temperature- $\mathrm{H}_{2} \mathrm{O}$ conditions appropriate for crust-derived magmas are in perfect agreement with those inferred from magnetotelluric data, strongly suggesting that the Tibetan bright spots image present-day pluton assembly in the middle crust, in a manner analogous to what happened during the Miocene to form the leucogranite plutons now exposed southward in the High Himalaya range.
\end{abstract}

\section{INTRODUCTION}

The India-Asia collision started at 55-45 Ma (Besse et al., 1984; Patriat and Achache, 1984 ) and generated the Himalaya range and the adjacent Tibetan Plateau, both of which are consequences of crustal thickening and uplift during continental convergence (Gansser, 1964; Dewey and Burke, 1973; Molnar and Tapponnier, 1978). The main magmatic products of the collision are the Miocene High Himalayan leucogranites, which form $\sim 12$ lensoid bodies several kilometers wide emplaced in the middle crust atop a crustal slice of metapelite, which preserves evidence of partial- melting events (Le Fort, 1975). Field relationships, as well as geochemical and experimental evidence, all indicate that the magmas prior to the leucogranites were most probably derived via dehydration melting of muscovite in the underlying metapelites (Deniel et al., 1987; Le Fort et al., 1987; France Lanord and Le Fort, 1988; Inger and Harris, 1993 ; Searle et al., 
1997), at low melt fractions (<10 w+\%), at pressures of 600-800 MPa, and in the temperature range $750-800{ }^{\circ} \mathrm{C}$ (Patino Douce and Harris, 1998 ). Such a temperature range is consistent with forward-modeling results of the thermal relaxation of thickened crust, when coupled to shear heating along main thrust faults (England et al., 1992; Henry et al., 1997; Harrison et al., 1998; Beaumont et al., 2001).

Thermobarometric work carried out on the top contact aureole of some High Himalayan leucogranites has shown that they were at $400 \pm 50 \mathrm{MPa}$ during intrusion and cooling (Guillot et al., 1995). Such a pressure is demanded by magmatic muscovite crystallization and has been confirmed by hydrothermal phase equilibria on two High Himalayan leucogranites (Scaillet et al., 1995). In addition, these phase equilibria have shown that the High Himalayan leucogranites were near-liquidus (crystal poor, <10 wt\% crystals) magmas when emplaced in the middle crust and contained 5-7 w†\% dissolved $\mathrm{H}_{2} \mathrm{O}$. Calculated melt-crystallization paths (Fig. 1A) show that during magma cooling, the melt's water content increased as a consequence of quartz and feldspar precipitation, reaching an $\mathrm{H}_{2} \mathrm{O}$ solubility of $\sim 8-9$ w $\%$ at $400 \mathrm{MPa}$ (Scaillet et al., 1995). Owing to the near-eutectic composition of the High Himalayan leucogranite magmas, they remained largely crystal poor down to near-solidus conditions, where massive crystallization occurred in the last 20 ${ }^{\circ} \mathrm{C}$ of cooling (Fig. 1B). This behavior implies that cooling leucogranite magmas will have their geophysical properties (e.g., viscosity, conductivity) dominated by those of the melt phase over most of their crystallization interval $\left(640-800{ }^{\circ} \mathrm{C}\right.$, Fig. 1). From this inference it can be anticipated that crystal effects on bulk High Himalayan leucogranite electrical resistivity become critical only at temperatures below $660^{\circ} \mathrm{C}$, whereas in the range $660-800{ }^{\circ} \mathrm{C}$, the liquid phase dominates the electrical properties of High Himalayan leucogranites and the crystals behave as insulator materials embedded in a conductive matrix.

\section{RESISTIVTYY OF HIMALAYAN LEUCOGRANITES}

These petrologic constraints on both the High Himalayan leucogranite compositions and the conditions during genesis and emplacement can be combined with resistivity measurements performed on hydrous granite melts (Gaillard, 2004 ) to model the conductivity behavior of High Himalayan leucogranite magmas. The laboratory work has shown that both water and alkalies are the main factors responsible for the dramatic conductivity increase observed in hydrous melts relative to dry ones (Gaillard, 2004). Figure $\underline{2}$ shows the effect of varying the water content and temperature of leucogranite melts on their electrical resistivity. It can be seen that, given the water contents and temperature constraints for typical High Himalayan leucogranites, such magmas have resistivities between 1.5 and $3 \Omega \mathrm{m}$ during emplacement in the middle crust $\left(750-800{ }^{\circ} \mathrm{C}\right)$, and they reach resistivity 
values higher than $10 \Omega \mathrm{m}$ during their solidification $\left(650^{\circ} \mathrm{C}\right)$. The source region of High Himalayan leucogranites will contain a melt with broadly similar compositional and temperature characteristics. However, in contrast to High Himalayan leucogranites, which are crystal-poor magmas during most of their evolution, their source rocks have a melt fraction of $\sim 6-8 \mathrm{wt} \%$ (Patino Douce and Harris, 1998) (Fig. 1B). Under these conditions, the solid-phase framework (i.e., the residual phases of the melting reaction) will have a significant, if not dominant, impact on the bulk-rock resistivity, increasing it by several orders of magnitude if the melt occurs within isolated small pockets, owing to the very high resistivity of rock-forming minerals (Roberts and Tyburczy, 1999; Partzsch et al., 2000 ; Schilling and Partzsch, 2001 ).

\section{COMPARISON WTH TIBETAN BRIGHTSPOTS}

These improved constraints on electrical properties of crust-derived magmas can be directly compared with geophysical signatures obtained from probing the Tibetan crust (Pham et al., 1986; Hirn et al., 1997; Owens and Zandt, 1997 ; Wei et al., 2001; Francheteau et al., 1984; Nelson et al.., 1996; Brown et al., 1996; Makovsky et al., 1996; Kind et al., 1996; Chen et al.., 1996; Li et al., 2003). Several geophysical investigations have indicated the presence of partially melted crust in Tibet, emphasizing the structural analogies between the High Himalayan range and the northern Tibetan crust (Nelson et al., 1996; Brown et al., 1996; Makovsky et al., 1996; Kind et al., 1996 ; Chen et al., 1996; Li et al., 2003). In particular, seismic bright spots imaged by the INDEPTH project have generally been interpreted as the culmination of a partial-melting process (Nelson et al., 1996; Brown et al., 1996; Makovsky et al., 1996; Kind et al., 1996; Chen et al., 1996; Li et al., 2003). They are located at 15-18 $\mathrm{km}$ depth, which agrees well with the pressure estimated for High Himalayan leucogranite intrusions in the Himalayas (Guillot et al., 1995). Magnetotelluric measurements have retrieved associated resistivities down to $3 \Omega \cdot \mathrm{m}$ (Pham et al., 1986; Brown et al., 1996), in agreement with what is expected from a crystal-poor High Himalayan leucogranite during its emplacement (Fig. 2). Bright spots also correspond to areas with high heat fluxes (Francheteau et al., 1984 ). On this basis, and in agreement with previous suggestions (Nelson et al., 1996), it appears likely that such zones of high conductivity probably correspond to local accumulations of crustderived melts, which ponded on top of a thick horizon of partially melted crustal rocks. That High Himalayan leucogranites and bright spots broadly lie at the same structural horizon suggests that Indian crust might be currently subducting under southern Tibet (Zhao et al., 1993), having bypassed the Indus-Tsangpo suture zone so that the crust slice that was parental to High Himalayan leucogranites during the Miocene is currently melting beneath Tibet. Whereas geophysical evidence so far gathered across Tibet neither proves nor disproves such a possibility (Hauck et al., 1998; Alsdorf et al., 1998 ), we note that post-Miocene leucogranite magmatism has been found in 
northern Tibet, in the Ulugh Muztagh area (McKenna and Walker, 1990), indicating that lithologies conducive to muscovite breakdown and attendant leucogranite magma production exist in the sub-Tibetan crust. However, northern Tibet is characterized by widespread, though volumetrically minor, occurrences of mafic lavas, which point to pressure-temperature conditions that are appropriate for mantle melting in this region (Turner et al., 1993; Ding et al., 2003). In contrast, in southern Tibet, geophysical evidence for a rather cold upper mantle (Molnar and Chen, 1983; Alsdorf and Nelson, 1999) argues for crustal melting being driven without heat advection from the mantle, as demonstrated for the High Himalayan leucogranites (Deniel et al., 1987). Mantle- derived melts have temperatures largely above $1000^{\circ} \mathrm{C}$ and thus conductivities possibly much lower than $1 \Omega \cdot \mathrm{m}$; that such conductivities have not been recorded in southern Tibet also supports a crustal origin $(<800$ ${ }^{\circ} \mathrm{C}$ ) for the melted layers in the middle to lower crust of southern Tibet.

\section{RUID OR MELT?}

The interpretation of bright spots as zones of melt accumulation in the middle crust is not unique. Detailed deconvolution of seismic signatures has led some workers to conclude that such geophysical anomalies are best interpreted as local accumulations of aqueous saline fluids instead of silicic melts (Makovsky and Klemperer, 1999). Upon full crystallization, leucogranite magmas release $\sim 5-6$ wt\% of aqueous fluids, because crystallizing hydrous minerals take up only a trivial part of the water dissolved in the melt (Scaillet et al., 1995). Thus, the presence of crystallizing leucogranites demands some local accumulation of fluids upon magma solidification. A considerable amount of free fluid, -10 vol\%, is also required if bright spots are interpreted as markers of pervasive saline fluid pockets (Makovsky and Klemperer, 1999). Because of the demonstrably fluid-absent status of middle- to lower-crustal lithologies (Yardley and Valley, 1997; Clemens and Watkins, 1998), the interpretation of bright spots as free aqueous fluids at $15-20 \mathrm{~km}$ depths also demands that some peculiar conditions be reached in the Tibetan crust, and a nearby crystallizing hydrous magma as the source of fluids is one obvious possibility. We thus suggest that some of the bright spots imaged by geophysical surveys could correspond to expelled fluids still locked within the top of a hot granitic intrusion, having not yet been scavenged by the active hydrothermal system that operates near and across any cooling pluton, which implies that the magma source of fluids has just fallen below its solidus. In this view, the occurrence of a large amount of fluids in the middle crust requires that molten granite be present immediately beneath those levels rich in fluids, and thus both melt and fluid could be collectively responsible for seismic and electrical bright spots (see Li et al., 2003 ). The important point is that the petrologic and experimental constraints show that the two differing interpretations with respect to the nature of Tibetan bright spots (melts or 
fluids) are not exclusive of each other, but instead are required by what is known about the geologic evolution of crust-derived melts.

An argument against the presence of melt has been that it would require a very high geothermal gradient to sustain magmatic temperatures at middlecrustal depths (Makovsky and Klemperer, 1999). We note, however, that High Himalayan leucogranites were intruded into middle crust whose preintrusion temperatures have been estimated to be lower than $400{ }^{\circ} \mathrm{C}$ (Guillot et al., 1995 ; Copeland et al., 1990). That is, High Himalayan leucogranite plutons are not built in situ, but instead are due to magmas that were produced several kilometers below the level of emplacement indicated by their present-day exposure. The melts formed at $-600-800 \mathrm{MPa}$, according to thermobarometric and experimental constraints, and were subsequently transferred upward through the crust via dikes, owing to the low viscosity and density of the melts (Scaillet et al., 1996). By analogy, we thus infer that bright spots are local accumulations of melt batches produced at depths (12-14 $\mathrm{km}$ ) with pressures of $\sim 400 \mathrm{MPa}$, in agreement with previous interpretations (Nelson et al., 1996; Li et al., 2003 ). The presence of intrusive magma bodies is thus likely to affect the local geotherm, but does not necessarily imply a high geothermal gradient on a regional scale. Therefore, we conclude that bright spots are markers of molten granitic plutons in the middle crust. The overall good match between (1) the restored pressure-temperature- $\mathrm{H}_{2} \mathrm{O}$ and resistivity characteristics of crust-derived plutons intrusive in the Himalaya chain and (2) those plutons inferred from geophysical surveys beneath Tibet suggests that the processes that produced High Himalayan leucogranite magmas in the Miocene are operating now beneath Tibet (Wu et al., 1998; Grujic et al., 2002).

\section{ACKNOWEDGMENTS}

The manuscript benefited from constructive reviews of Lothar Ratschbacher and Tracy Rushmer.

\section{REERENCES CIIED}

Alsdorf, D., and Nelson, K.D., 1999, Tibetan satellite magnetic low: Evidence for widespread melt in the Tibetan crust: Geology, 27, 943-946.

Alsdorf, D., Brown, L., Nelson, K.D., Ross, A., Makovsky, Y., Klemperer, S., and Zhao, W., 1998, Crustal deformation of the Lhasa terrane, Tibet Plateau from INDEPTH seismic reflection profile: Tectonics, 17, 501-520.

Beaumont, C., Jamieson, R.A., Nguyen, M.H., and Lee, B., 2001, Himalayan tectonics explained by extrusion of a low-viscosity crustal channel coupled to focused surface denudation: Nature, 414, 738-742. 
Besse, J., Courtillot, V., Pozzi, J.P., Westphal, M., and Zhou, Y.X., 1984, Paleomagnetic estimates of crustal shortening in the Himalayas thrusts and Zangbo suture: Nature, 311, 621-626.

Brown, L.D., Zhao, W., Nelson, K.D., Hauck, M., Alsdorf, D., Cogan, M., Clark, M., Liu, X., and Che, J., 1996, Bright spots, structure, and magmatism in southern Tibet from INDEPTH seismic reflection profiling: Science, 274, 16881690.

Chen, L., Booker, J., Jones, A.G., Wu, N., Unsworth, M.J., Wei, W., and Tan, H., 1996. Electrically conductive crust in southern Tibet from INDEPTH magnetotelluric surveying: Science, 274, 1694-1696.

Clemens, J., and Watkins, J.M., 1998, The fluid regime of high temperature metamorphism during granitoid magma genesis: Contributions to Mineralogy and

Petrology, 140,

600-606.

Copeland, P., Harisson, T.M., and Le Fort, P., 1990, Age and cooling history of the Manaslu granite: Implications for Himalayan tectonics: Journal of Volcanology and Geothermal Research, 44, 33-50.

Deniel, C., Vidal, P., Fernandez, A., Le Fort, P., and Peucat, J.J., 1987, Isotopic study of the Manaslu granite (Himalaya, Nepal): Inferences on the age and source of the Himalayan leucogranites: Contributions to Mineralogy and Petrology, 96,

78-92.

Dewey, J.F., and Burke, K., 1973, Tibetan, Variscan and Precambrian basement reactivations: Products of continental collision: Journal of Geology, 81 ,

683-692.

Ding, L., Kapp, P., Zhong, D., and Deng, W., 2003, Cenozoic volcanism in Tibet: Evidence for a transition from oceanic to continental subduction: Journal of Petrology, 44 ,

1833-1865.

England, P., Le Fort, P., Molnar, P., and Pêcher, A., 1992, Heat sources for Tertiary metamorphism and anatexis in the Annapurna-Manaslu region central Nepal: Journal of Geophysical Research, 97, 2107-2128.

France Lanord, C., and Le Fort, P., 1988, Crustal melting and granite genesis during the Himalayan collision orogenesis: Royal Society of Edinburgh Transactions, 79 , 183-195.

Francheteau, J., Jaupart, C., Xian, J.S., Wen-Hua, K., De-Lu, L., Jia-Cha, B., Hun-Pin, W., and Hsia-Yeu, D., 1984, High heat flow in southern Tibet: Nature, 307, 32-36. 
Gaillard, F., 2004, Laboratory measurements of electrical conductivity of hydrous and dry silicic melts under pressure: Earth and Planetary Science Letters, 218 ,

215-228.

Gansser, A., 1964, Geology of the Himalayas: New York, Wiley-Interscience, 289

Grujic, D., Hollister, L., and Parrish, R.R., 2002, Himalayan metamorphic sequence as an orogenic channel: Insight from Bhutan: Earth and Planetary Science Letters,

198,

177-191.

Guillot, S., Le Fort, P., Pêcher, A., Roy-Barman, M.R., and Aprahamian, J., 1995, Contact metamorphism and depth of emplacement of the Manaslu granite (central Nepal): Implications for Himalayan orogenesis: Tectonophysics, 241, 99-119.

Harrison, T.M., Grove, M., Lovera, O.M., and Cat los, E.J., 1998, A model for the origin of Himalayan anatexis and inverted metamorphism : Journal of Geophysical Research, 103, 27017-27032.

Hauck, M.L., Nelson, K.D., Brown, L.D., Zhao, W., and Ross, A.R., 1998, Crustal structure of the Himalayan orogen at $90^{\circ}$ east longitude from project INDEPTH deep reflection profiles: Tectonics, 17, 481-500.

Henry, P., Le Pichon, X., and Goffé, B., 1997, Kinematic, thermal and petrological model of the Himalayas: Constraints related to metamorphism within the underthrust Indian crust and topographic elevation: Tectonophysics, 273, $31-56$.

Hirn, A., Sapin, M., Lépine, J.C., Diaz, J., and Mei, J., 1997, Increase in melt fraction along a south-north traverse below the Tibetan Plateau: Evidence from seismology: Tectonophysics, 273, 17-30.

Inger, S., and Harris, N., 1993, Geochemical constraints on leucogranite magmatism in the Langtang Valley, Nepal Himalaya: Journal of Petrology, 34, $345-368$.

Kind, R., Ni, J., Zhao, W., Wu, J., Yuan, X., Zhao, L., Sandvol, E., Reese, C., Nabelek, J., and Hearn, T., 1996, Evidence from earthquake data for a partially molten crustal layer in southern Tibet: Science, 274, 1692-1694.

Le Fort, P., 1975, Himalayas: The collided range: American Journal of Science, 275 ,

Le Fort, P., Cuney, M., Deniel, C., France-Lanord, C., Sheppard, S.M.F., Upreti, B.N., and Vidal, P., 1987, Crustal generation of the Hima layan leucogranites: Tectonophysics, 
Li, S., Unsworth, M.J., Booker, J.R., Wei, W., Tan, H., and Jones, A.G., 2003, Partial melt or aqueous fluid in the mid-crust of southern Tibet?: Constraints from INDEPTH magnetotelluric data: Geophysical Journal International, 153, 289-304.

Makovsky, Y., and Klemperer, S.L., 1999, Measuring the seismic properties of Tibetan bright spots: Evidence for free aqueous fluids in the Tibetan middle crust: Journal of Geophysical Research, 104, 10795-10825.

Makovsky, Y., Klemperer, S., Ratschbacher, L., Brown, L.D., Li, M., Zhao, W., and Meng, F., 1996, INDEPTH wide angle reflection observation of P-wave to S-wave conversion from crustal bright spots in Tibet: Science, 274, 1690-1691.

McKenna, L.W., and Walker, J.D., 1990, Geochemistry of crustally derived leucocratic igneous rocks from the Ulugh Muztagh area, northern Tibet and their implications for the formation of the Tibetan Plateau: Journal of Geophysical Research, 95, 21483-21502.

Molnar, P., and Chen, W.P., 1983, Focal depths and fault plane solutions of earthquakes under the Tibetan Plateau: Journal of Geophysical Research, 88, 1180-1196.

Molnar, P., and Tapponnier, P., 1978, Active tectonics of Tibet: Journal of Geophysical Research, 83, 5361-5375.

Nelson, K. D. 27 others,. , 1996, Partially molten middle crust beneath southern Tibet: Synthesis of project INDEPTH results: Science, 274, 1684-1688.

Owens, T., and Zandt, G., 1997, Implications of crustal property variations for models of Tibetan Plateau evolution: Nature, 387, 37-43.

Partzsch, G.M., Schilling, F.R., and Arndt, J., 2000, The influence of partial melting on the electrical behavior of crustal rocks: Laboratory examinations, model calculations and geological interpretations: Tectonophysics, 317, 189203.

Patino Douce, A., and Harris, N., 1998, Experimental constraints on Himalayan anatexis: Journal of Petrology, 39, 689-710.

Patriat, P., and Achache, J., 1984, India-Asia collision chronology has implications for crustal shortening and driving mechanism of plates: Nature, 311 ,

615-621.

Pham, V.N., Boyer, D., Therme, P., Yuang, X.C., Li, L., and Jin, G.Y., 1986, Partial melting zones in the crust in southern Tibet from magnetotelluric results: Nature,

311 . 310-314. 
Roberts, J.J., and Tyburczy, J.A., 1999, Partial-melt electrical conductivity: Influence of melt composition: Journal of Geophysical Research, 104, 70557065.

Scaillet, B., Pichavant, M., and Roux, J., 1995, Experimental crystallisation of leucogranite magmas: Journal of Petrology, 36, 663-705.

Scaillet, B., Holtz, F., Pichavant, M., and Schmidt, M., 1996, Viscosity of Himalayan leucogranites: Implications for mechanisms of granitic magma ascent: Journal of Geophysical Research, 101, 27691-27699.

Schilling, F.R., and Partzsch, G.M., 2001, Quantifying partial melt fraction in the crust beneath the central Andes and the Tibetan Plateau: Physics and Chemistry of the Earth, 239-246.

Searle, M.P., Parrish, R.R., Hodges, K.V., Hurford, A., Ayres, M.W., and Whitehouse, M.J., 1997, Shisha Pangma leucogranite, south Tibetan Himalaya: Field relations, geochemistry, age, origin, and emplacement: Journal of Geology, 105 , 295-317.

Turner, S., Hawkesworth, C., Liu, J., Rogers, N., Kelley, S., and van Calsteren, P., 1993, Timing of Tibetan uplift constrained by analysis of volcanic rocks: Nature, 364 ,

50-53.

Wei, W., Unsworth, M., Jones, A., Booker, J., Tan, H., Nelson, D., Chen, L., Li, S., Solon, K., Bedrosian, P., Jin, S., Deng, M., Ledo, J., Kay, D., and Roberts, B., 2001, Detection of widespread fluids in the Tibetan crust by magnetotelluric studies:

Science, 292,

716-718.

Wu, C., Nelson, K.D., Wortman, G., Samson, S.D., Yue, Y., Li, J., Kidd, W.S.F., and Edwards, M.A., 1998, Yadong cross structure and South Tibetan detachment in the east central Himalaya: Tectonics, 17, 28-45.

Yardley, B.W.D., and Valley, J.W., 1997, The petrologic case for a dry lower crust:: Journal of Geophysical Research, 102, 12173-12185.

Zhao, W., and Nelson, K. D. Project INDEPTH team,. , 1993, Deep seismic reflection evidence for continental underthrusting beneath southern Tibet: Nature, 366, 557-559. 


\section{FGURES}
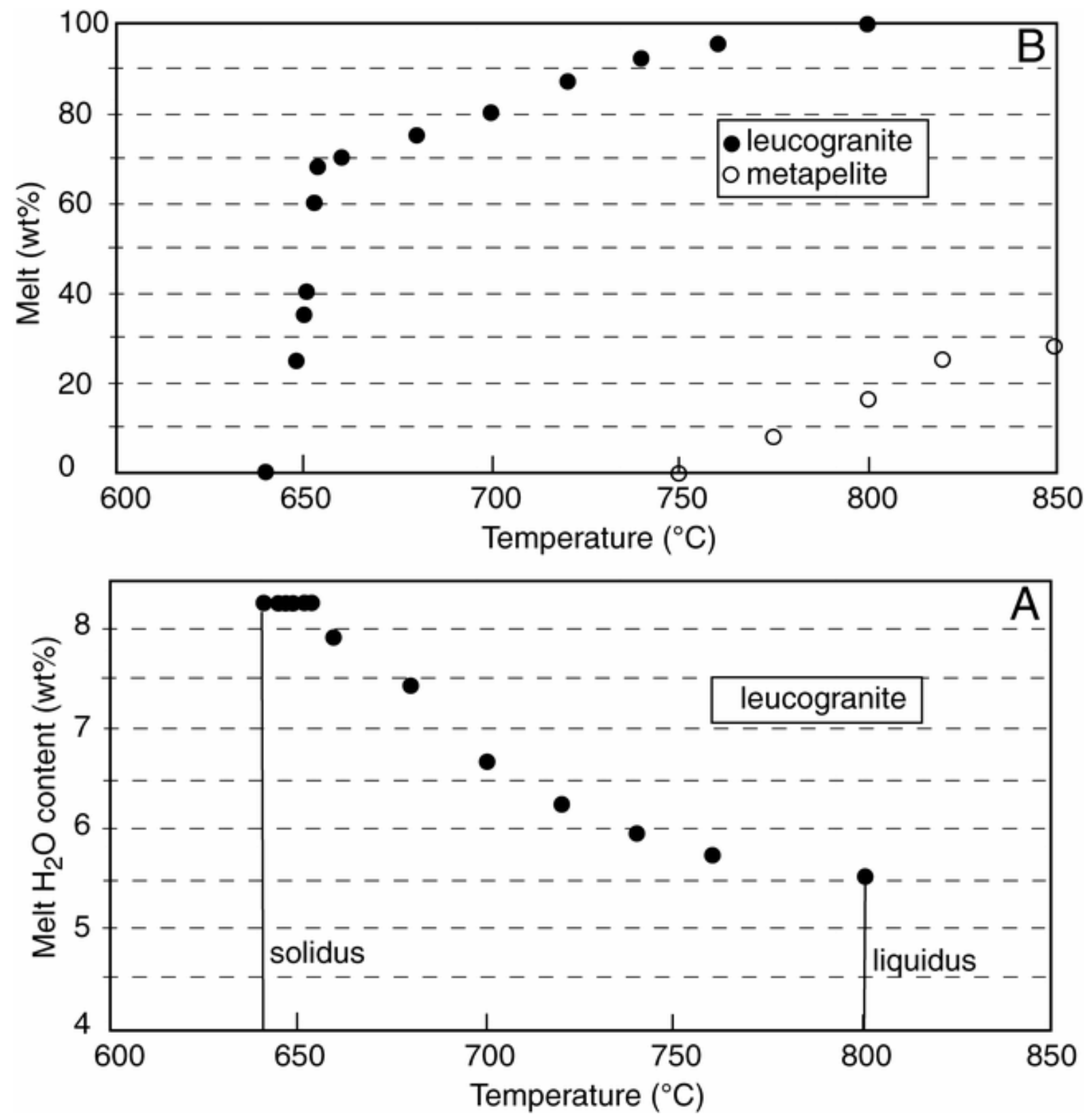

Figure 1. A: Evolution of water content of crystallizing leucogranite magma as constrained from phase-equilibrium experiments on High Himalayan leucogranite $(\mathrm{HHL})$ at $400 \mathrm{MPa}$ (Scaillet et al., 1995). Near constancy of water content at near-solidus conditions is due to attainment of saturation conditions with respect to water at $400 \mathrm{MPa}$. B: Evolution of melt fraction (wt\%) during either leucogranite crystallization (Scaillet et al., 1995) or metapelite melting (Patino Douce and Harris, 1998). Partial melting of metapelite yields $\mathrm{HHL}$-like melts at $770-800{ }^{\circ} \mathrm{C}$, temperature range that corresponds to near-liquidus (crystal-poor) conditions of HHL magmas. 


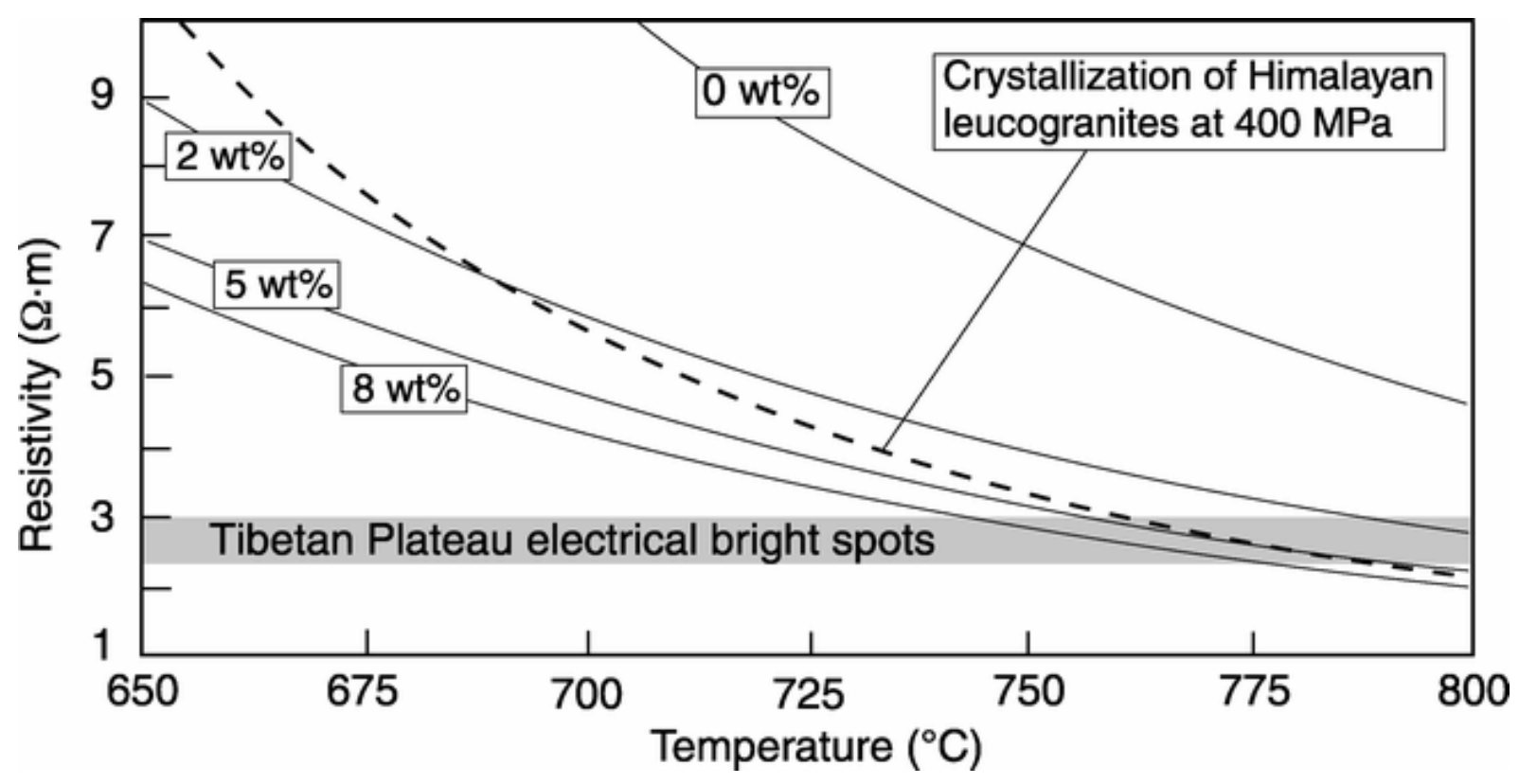

Figure 2. Resistivity of dry and hydrous leucogranite melts with $\mathrm{H}_{2} \mathrm{O}$ contents of 2, 5, and 8 wt\% (continuous lines), calculated after Gaillard (2004). Also shown is evolution of crystallizing High Himalayan leucogranite (HHL) magma (dashed line), calculated by using experimental constraints shown in Figure 1 from scaillet et al. (1995) and model of Gaillard (2004), effect of crystals incorporated by using Archie's law. Resistivity value associated with electrical bright spots observed in southern Tibetan Plateau by Nelson et al. (1996) is also shown as horizontal gray shaded band. 